\title{
Philip C.C. Huang, Code, Custom, and Legal Practice in China. The Qing and the Republic Compared
}

Stanford, Stanford University Press, 2001, 246 pp.

\section{Vincent Goossaert}

\section{(Q) OpenEdition}

\section{Journals}

Édition électronique

URL : http://journals.openedition.org/chinaperspectives/240

DOI : $10.4000 /$ chinaperspectives. 240

ISSN : 1996-4617

\section{Éditeur}

Centre d'étude français sur la Chine contemporaine

Édition imprimée

Date de publication : 1 février 2003

ISSN : 2070-3449

\section{Référence électronique}

Vincent Goossaert, «Philip C.C. Huang, Code, Custom, and Legal Practice in China. The Qing and the Republic Compared », China Perspectives [En ligne], 45 I january-february 2003, mis en ligne le 22 août 2006, consulté le 21 septembre 2020. URL : http://journals.openedition.org/chinaperspectives/240 ; DOI : https://doi.org/10.4000/chinaperspectives.240

Ce document a été généré automatiquement le 21 septembre 2020

(c) All rights reserved 


\title{
Philip C.C. Huang, Code, Custom, and Legal Practice in China. The Qing and the Republic Compared
}

\author{
Stanford, Stanford University Press, 2001, 246 pp.
}

\section{Vincent Goossaert}

1 Philip Huang set up a Los Angeles-based study group to examine Chinese law, and has created a collection with Stanford University Press, this being the sixth volume. This book is also the second part of an intended trilogy. Following his study on Qing civil law (Civil Justice in China, Representation and Practice in the Qing, 1996), he had planned to produce a volume on the Republican period, but found it more informative to present Republican civil law in contrast to that of the preceding period. This book is thus a new contribution to the history of Chinese law by an eminent authority in this field. But, by virtue of the book's comparative approach, it also amounts to a study on the political and social changes that took place during the first half of the twentieth century from a legal perspective, a viewpoint that is often neglected by historians, undoubtedly because it is generally regarded as too "technical".

2 The book is presented in two parts-the first, the shorter of the two, retraces the history of the code and the legal institutions from 1900-45. It recounts the work of the legal reform commissions during the decade from 1900 to 1910, which gave rise to new codes, both civil and penal, inspired notably by the German model. However, the draft civil code was never adopted, and a revised version based on the "civil" parts extracted from the Qing code remained in use until the promulgation of the civil code drawn up by the Kuomintang government in 1929-1930. Procedural reforms were, however, gradually applied from the latter years of the Qing period-separation of penal and civil law (which represented only "minor" matters in the Qing code and became a separate area), separation of the judiciary and the executive within the local administration, and the emergence of the legal profession. These developments in legal practices thus facilitated, not followed, the adoption of a law that was radically different from the Qing code. The second part of the book examines the similarities and the differences 
between Qing law and Republican law, in terms of the legal texts as well as the practices (through a sample of cases drawn from local archives), by means of five questions relating essentially to civil law-the conditional sale of land (dian), ownership of the topsoil (dual ownership of agricultural land), debts, support given to elderly parents, and family law as it applies to women (marriage, adultery and divorce). Philip Huang's writing style is clear and his arguments are well-constructed. It is a great credit to him that he has made such a subject intelligible to non-specialists, such as this reviewer.

On each point, the author endeavours to bring to the fore the "logic" (the ideological foundations) of the two codes, the practices of the judges, and "custom" (in fact, here, simply the practices common among the people). Sometimes the codes try to follow "custom", sometimes they rebuff it. On the whole, the contrast between the Qing and the 1929-30 codes appears larger than that between the real-life cases found in the archives from the Qing and Republican periods. In both kinds of archives, we find very similar issues, stemming from a popular practice that changed only slowly. Republican judges often tried to find compromises between the radically new logic of the 1929-30 code and traditional attitudes. Maybe this was because the code had unexpected consequences, maybe because the code itself retained traces of the paternalistic Qing ideology, or maybe simply because the judges still broadly shared the ancient "logic". But changes in the code as well as in jurisprudence moved along similar lines. Philip Huang sums up this evolution in two breaks: 1) from an agricultural economy to a capitalist economy (the former supporting a farmer's rights to his land and protecting him from usury and dispossession, and the latter recognising individual ownership, capital and investment); and 2) from a patriarchal law to an individualistic law, implying gender equality, marriage as a contract between two individuals, and the right of women to self-determination.

Without political prejudice, Philip Huang wants to highlight all the positive aspects of the Kuomintang legal undertaking by demonstrating the advances (women's rights and a market economy) made possible by the new code as well as the legal practices that go with it. One might wonder if the examples chosen are representative of the Republican laws as a whole. Property law and the status of women are areas in which the Kuomintang had a genuine, positive, modernistic agenda. In a different area, which borders on civil law (which interests this reviewer), i.e. the law relating to temples and the clergy, the evolution is quite different. Admittedly, there too we move from an absolutist model (under the Qing, the emperor was the only religious authority, and could declare a cult illicit and ban it), to another ruled exclusively by law. However, by its anti-religious laws, the Nanking government practiced theology and arbitrarily sorted, under cover of scientific justification, the cults which it authorised and those that had to be banned. The laws relating to temples (notably those of 1915 and 1928) also marked a greater interference by the state in an essentially private area and new prerogatives for the local authorities, who, notably, allowed themselves to seize land from religious foundations, as well as to deny the existence of certain types of organisations (temple corporations) which, although they were not formally protected by Qing law, were recognised in practice by the magistrates.

5 In short, Philip Huang's book paints a picture of the changes introduced by a code that stemmed from an imported ideology (free-market capitalism, giving priority to contracts between individuals as a source of social relationships). The adaptation of 
this ideology in the Chinese context is thus reflected in a mixed evolution in terms of liberties, increasing certain ones only to cut back on others. 